\title{
A VOZ NO ARQUIVO DIGITAL
}

Tereza Virginia de Almeida*

\begin{abstract}
RESUMO: O presente artigo tem como objetivo refletir sobre os impactos ocasionados nas ciências humanas pelo compartilhamento de arquivos auditivos e audiovisuais possibilitado pela contemporânea presença da internet. Para tanto, parte da hipótese de que o fenômeno representa uma guinada em direção à vocalidade que vem a trazer significativas transformações nas relações entre pensamento e linguagem, quando comparadas com a cultura do impresso. $O$ elemento central que se apresenta com a presença da voz enquanto materialidade se traduz em um processo de corporificação, em que o aspecto sensorial emerge como algo indissociável da ação comunicativa, ao contrário do que se dá com a impressão em papel e o consequente processo de autonomização do texto.
\end{abstract}

PALAVRAS-CHAVE: Voz. Humanidades. Arquivo. Imprensa. Corpo.

Em A palavra e as coisas, Michel Foucault nos permite inferir a vocação, desde sempre transdisciplinar, de tudo que venha a se tornar objeto para as ciências humanas que, segundo o filósofo, como fenômeno da modernidade, inventa sua própria noção de homem, uma noção até então inexistente para os séculos XVII e XVIII. Segundo Foucault, as ciências humanas "apareceram no dia em que o homem se constituiu na cultura ocidental, ao mesmo tempo como o que se deve pensar e o que se deve saber" (FOUCAULT, 1995, p. 362). O filósofo constrói, então, o seu "triedro dos saberes" (composto das ciências matemáticas e físicas, ciências que incluem a biologia, a linguística e a economia e as ciências filosóficas) e demonstra que, dessa formulação, as ciências humanas são, ao mesmo tempo, excluídas e sempre em vias de incluir-se, na medida em que, sem se encontrarem integralmente em nenhum dos saberes configurados, ganham existência somente por operar nos interstícios desses próprios saberes.

Nessa dinâmica, torna-se constitutivo mesmo de qualquer operação que se dê no cerne das ciências humanas o encaminhamento de suas reflexões para além das

Universidade Federal de Santa Catarina. Honorary visiting fellow em La Trobe University/ Australia (2013-2014). Bolsista sênior da Capes/Coordenação de Aperfeiçoamento de Pessoal do Nível Superior. Imeio: tvirginia2004@yahoo.com.br

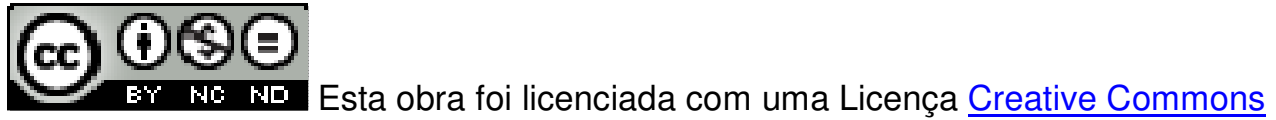

Texto Digital, Florianópolis, v. 9, n. 2, p. 20-34, jul./dez 2013. ANO. ISSNe: 1807-9288 
fronteiras daquilo que pode ser delineado como seu objeto: a abordagem da linguagem e dos artefatos do homem se encaminha para as margens da própria linguagem, tal como se dá na e pela literatura (FOUCAULT, 1995, p.373).

No atual contexto, em que a própria modernidade que inventou o homem o redefine em constante conexão com outros seres vivos e com as máquinas com que não cessa de interagir, o movimento na direção de outras disciplinas ou do próprio pensamento indisciplinado (como o de artistas, artesãos e mestres de saberes) parece ser a resposta produtiva ao pensamento em crise.

\section{Da escrita à vocalização}

A busca do conceito capaz de reunir os inúmeros artefatos que se oferecem hoje como objeto de análise e teorização, remete ao termo arquivo, tal como concebido por Foucault e retomado por Derrida, em perspectiva que dialoga com as contribuições da psicanálise. Plenamente articulável com o conceito de contemporaneidade, tal como proposto por Giorgio Agamben (AGAMBEN, 2009, p. 55-73), o conceito de arquivo pressupõe sempre uma operação de exclusão e inclusão. Enquanto "sistema geral de formação e transformação de enunciados" (FOULCAULT, 1995, p. 150), a palavra, tão em circulação em nosso cotidiano informatizado, contempla plenamente os objetos auditivos e audiovisuais em que se inscrevem a voz e o corpo, essa materialidade que, por sua vez, é compreendida por Jacques Derrida também sob a definição de arquivo.

Se Foucault acentua o caráter seletivo de todo arquivo ao trazer em si somente o que uma determinada cultura ou contexto compreende que seja passível de ser preservado, Jacques Derrida enfatiza a relação que o arquivo estabelece com a materialidade, ao se indagar em que momento aquilo mesmo que se dá às custas de um recalcamento, ou de uma exclusão, se transforma em "impressão", ou seja, se torna o conjunto efetivamente preservado e dado à reprodução (DERRIDA, 2001, p. 40). 
Desta forma, o que se entende hoje como arquivo digital apresenta, assim como o texto impresso e o manuscrito que se entrega à publicação, os mesmos elementos que possibilitam seu pertencimento à categoria dos arquivos. Entretanto, se o impresso se dá para além da seleção elaborada sobre o recalque do próprio corpo de que se origina (GUMBRECHT, 1998, p. 67-108), o que há de se dizer dos arquivos que se tornaram tão presentes em nosso cotidiano através do compartilhamento de filmes, vídeos, canções? O que dizer dos arquivos que presentificam enunciados através das vozes e dos corpos dos quais se originam?

Se a invenção da imprensa significou outra forma de lidar com os textos que passaram a formar um corpo próprio, separado do corpo do autor, a era digital traz de volta o corpo do qual se origina o texto, mas um corpo mediado pelas diferentes tecnologias capazes de registrar imagem e voz. O que muda, então, na produção e recepção de textos na medida em que arquivos auditivos e audiovisuais podem ser, em segundos, recebidos através de um computador e reorganizados em arquivos individuais em mp3, wma e outros formatos? Penso não somente na canção, mas em video aulas, entrevistas, palestras, tudo o que até o momento as ciências humanas priorizaram tratar a partir do texto impresso.

Basta que se acesse o youtube para ver/ouvir, por exemplo, os próprios teóricos aqui citados. Assim, o pensamento ganha corpo, voz. E o tempo presente passa a ser essa incessante convivência de arquivos originários de múltiplos tempos, pelos quais se transita em questão de cliques. Da mesma forma, podemos vivenciar, a qualquer momento de nossos cotidianos, a recepção dos cantos de Elis Regina, de Carmen Miranda, Edith Piaf, que nos surgem tão rapidamente quanto os das cantoras ainda em início de carreira e dos inúmeros amadores que gravam arquivos e os disponibilizam na rede.

A voz desafia muitos dos pressupostos dos estudos literários, cuja tradição se delineia em torno do impresso, mas que já se abala, há algumas décadas, com as novas demandas que se impõem pelos estudos da oralidade, principalmente 
em um país como o Brasil, possuidor de uma forte tradição na poesia popular, dos cantadores à música urbana, e onde o rádio e a televisão se estabelecem no século passado, sem que tenha havido propriamente a configuração de uma tradição letrada.

A oralidade, entretanto, não nos coloca diante da mera substituição de um suporte por outro, mas nos leva a indagar sobre os limites de nossas disciplinas para tratar dos novos arquivos que se nos apresentam. E, nesse sentido, esclareço que não falo aqui da imagem do corpo ou do arquivo enquanto imagem e sim da presentificação da materialidade da qual se origina a voz. Ou seja, estou interessada na gestualidade de um filósofo em interação com sua fala, em seu timbre, a região em que fala, mas não em quem dirigiu e/ou definiu roteiro, cenário, locação, etc., ou o que quer que envolva outras formas de ocupação dos lugares de autoria. O que me importa é a voz que, até então recalcada, se faz ouvir e esse corpo do qual emana a voz, corpo que se torna possível ver no ato mesmo de emissão vocal, mas que é virtualmente recebido. Essa voz que se tornara silenciosa na folha de papel e esse corpo que dera lugar ao corpo textual agora ressurgem no espaço virtual entremeados pela escrita, a complementar e desafiar a leitura, a demandar ouvidos para além de olhos.

\section{A voz e seus desafios}

O caráter interdisciplinar desta empreitada já foi assinalado por Paul Zumthor, ao afirmar que "uma ciência da voz deveria abarcar tanto uma fonética quanto uma fonologia, chegar até uma psicologia da profundidade, uma antropologia e uma história. Deveria ultrapassar amplamente o domínio vocal propriamente dito. Com efeito, antes da voz, há o silêncio". E completa: "A língua é mediatizada, levada pela voz. Mas a voz ultrapassa a língua; é mais ampla do que ela, mais rica”. (ZUMTHOR, 1999, p. 62-63). É no cerne mesmo do desafio à reflexão inter e transdisciplinar lançado por Paul Zumthor que a voz nos há de lançar para algum lugar fora da linguagem, na qual o próprio humano já não mais se faz objeto. 
Edgar Morin traz à lembrança a observação de Piaget acerca da interdependência das ciências entre si, a que teria denominado o círculo das ciências. A voz, enquanto objeto, parece colocar-se no lugar onde Morin percebe o risco da organização disciplinar: "A fronteira disciplinar, sua linguagem e seus conceitos próprios vão isolar a disciplina em relação às outras e em relação aos problemas que se sobrepõem às disciplinas" (MORIN, 2003, p. 106). Ou seja, o que se busca aqui são os elementos que permitem à voz se furtar a ser abordada pelas ciências da linguagem. Neste sentido, a voz não somente ultrapassa a língua, mas as fronteiras das ciências humanas, na medida em que, assim como o corpo, enfatiza aquilo que no humano é, além ou aquém da cultura, físico e biológico.

Se o desafio da transdisciplinaridade reside na busca por uma revalorização na educação do papel da sensibilidade, a abordagem e a reflexão acerca da voz parecem colocar em circulação a demanda por uma renovada abordagem em torno da linguagem que talvez na busca mesmo de seus métodos encontre como premissa a ausência do método e a ultrapassagem, mesmo que provisória, da disciplina.

Este desafio, por sua vez, parece integrar a crise do pensamento ao demandar que se inscreva o corpo e as relações sensoriais que estabelece com o mundo, ou seja, este vasto campo que foi excluído pela configuração das ciências humanas, centradas, até então, na racionalidade.

Michael Heim identifica no próprio surgimento do processador de textos, ou seja, na liberação da escrita da materialidade do papel, a transformação radical do pensamento tornado dinâmico e fragmentário, pela possibilidade de editar, inserir cortar, substituir, etc., oferecidas pela escrita na tela (HEIM, 1987, p. 10).

$\mathrm{Na}$ verdade, segundo Heim, com o computador, o pensamento passa a acontecer na tela, sem que se dê a preocupação com a formulação de pensamentos, em momento anterior ao ato da escrita, e nem mesmo com a 
ordem do que se escreve, já que, a princípio, meio e fim podem ser facilmente intercambiados (HEIM, 1993, p. 5)

Para além disto, é preciso pensar nos diversos ambientes em que se dá a escrita em tela e que hoje vão muito além do processador: blogues, redes sociais, espaços para comentários, etc. A cada dia surgem novas formas de atender à demanda pela interatividade que, por sua vez, transforma a escrita e as fronteiras entre quem lê e escreve.

Antes de se pensar na voz que pode ser transmitida virtualmente por arquivos auditivos e audiovisuais, é preciso estar atento ao fato de que a escrita virtual se oferece como recurso que se aproxima da oralidade. Tal como observa Pierre Lévy, a escrita virtual reconstitui, em escala maior, a presença da mensagem e de seu contexto que caracteriza a comunicação oral (LÉVY, 1996, p. 39).

Cada vez mais próxima da conversação, a escrita virtual, por sua própria interatividade, está sempre a buscar seu receptor e suas referências contextuais, ao contrário da escrita que se dá para a página impressa e que pressupõe o distanciamento entre os atos de recepção e produção, bem como a impossibilidade de prever os inúmeros contextos em que será recebida. "Para começar, o leitor em tela", diz Lévy, "é mais ativo que o leitor em papel: ler em tela é, antes mesmo de interpretar, enviar um comando a um computador para que projete aquela realização parcial do texto sobre uma superfície luminosa" (LÉVY, 1996, p. 40). Lévy observa, ainda, que na interação virtual, escrita e leitura passam a ser intercambiáveis (LÉVY, 1996, p. 46). Entretanto, isto não significa, para o pensador, o fim da escrita, o fim do texto. Ao contrário, para o autor, a escrita virtual parece colocar o texto em sua pré-história, como se a escrita tivesse sido reinventada (LÉVY 1996, p. 50).

Pierre Lévy, com isto, não está a sugerir que o destino do texto ou sua busca tenha sido sempre a de se aproximar da comunicação oral, reproduzir sua dinâmica e que teria encontrado o obstáculo da materialidade do impresso que 
só agora seria superada pela virtualização. Entretanto, deixa claro o quanto o hipertexto aproxima os agentes envolvidos das interações comunicativas realizadas através da oralidade.

Com que estratégias, então, e a partir de que premissas se vai, daqui em diante, abordar o que denominamos texto se as teorias em torno deste se modelaram em função do escrito? (ALMEIDA, 2011). O que muda quando somos confrontados com a voz, com a escuta, com a imagem dos corpos dos quais se originam as palavras e não mais com a leitura?

É possível pensar que não se está diante de um novo objeto, já que rádio e televisão estão presentes no cotidiano brasileiro desde o século XX. Entretanto, há de se considerar dois fatores. O primeiro corresponde ao processo de superação das fronteiras entre alta e baixa cultura que se foi apresentando de forma cada vez mais enfática, a partir dos anos 60, e que retirou do centro da atenção a cultura livresca levando os estudos literários a incorporar os artefatos advindos da indústria cultural, até então excluídos porque regidos não pela lógica do campo erudito, mas pelas leis do mercado (BOURDIEU, 1992, p, 99-182). O segundo fator diz respeito à própria inversão que a presença doméstica do computador ocasionou nos lugares das palavras falada e escrita. Hoje, o escrito não é mais o lugar da palavra burilada. Ao contrário, todos podem, em segundos, registrar intervenções em redes sociais, sem muita preocupação com a "correção" da linguagem e, até mesmo, publicar na rede textos com nítidas marcas de oralidade. Por outro lado, os arquivos auditivos e audiovisuais requerem, no mínimo, algum domínio sobre as tecnologias de gravação e edição.

Esses fenômenos geram mudanças também no âmbito das práticas pedagógicas. Já faz algum tempo que nossas aulas mudaram. Depois do youtube, os exemplos e objetos de análise aparecem em instantes nas superfícies dos quadros brancos, com o auxílio dos aparatos tecnológicos. Isto sem falar no recente advento da plataforma moodle, que substitui a sala de aula 
por videoaulas e possibilita o envio constante aos alunos de arquivos textuais, auditivos e audiovisuais.

Para aqueles que, como nós, professores, lidam cotidianamente com as transformações comportamentais apresentadas pelas diferentes gerações, as diferenças ocasionadas nos receptores com as mudanças tecnológicas tocam bem de perto. Temos acompanhado e interagido com jovens capazes de navegar simultaneamente por diversos sítios virtuais, mas resistentes à leitura de romances longos. Para quem tem, dentro desse contexto, a tarefa de estimular a reflexão e se continuamos desejando fazê-lo, é preciso enfrentar muitos desafios.

Minha atuação, a partir de 2009, no ensino virtual, por exemplo, levou-me a aprender a seccionar as videoaulas em vários arquivos de, no máximo, quinze minutos, não apenas como um processo de edição, mas enquanto microaulas mesmo, providas de núcleos semânticos independentes umas das outras. E logo aprendi que meu aluno presencial tende a considerar repetitivo o que, há quinze anos, era tido como mera reiteração, o que requer a incorporação de uma série de estratégias e de recursos, já que a sensibilidade contemporânea pressupõe uma percepção do tempo totalmente diversa, marcada que é pela aceleração e pela simultaneidade. Ou seja, também o professor, confrontado com as mudanças em seu receptor, se vê diante da demanda por transformações em sua performance.

A rápida e constante circulação de vozes em arquivos digitais deve pressupor diferentes formas de recepção se as compararmos com a palavra escrita. A interpretação de um texto pressupõe não somente a inferência de sentido, mas a percepção dos recursos utilizados pelo escritor em sua interação com a língua. Neste sentido, o que prevalece é justamente a percepção da criatividade do escritor ao trabalhar com as palavras, com elementos pré-existentes. O que Zumthor deixa claro, entretanto, como já abordado, é que a voz antecede e ultrapassa a língua. Pode-se dizer da voz aquilo que Paul Zumthor afirma acerca 
da performance: embora participante de um processo global de significação, a voz não se oferece como objeto semiótico na medida em que ultrapassa a noção de signo (ZUMTHOR, 2007, p. 75).

O que se coloca, portanto, como o desafio central, a ser enfrentado, diz respeito ao fato de que qualquer texto, um poema, um romance, uma aula ou uma canção, que se presentifique através da voz, demanda uma abordagem que possa inscrever a própria voz enquanto instância singular que ultrapassa, tal como já apontou Adriana Cavarero, as entidades fictícias configuradas pela tradição filosófica, sob as designações de 'sujeito' e 'indivíduo'. A singularidade da voz emerge não somente do logos, mas do corpo e de sua finitude (CAVARERO, 2011, p. 194-201).

Tal como assinala Silvia Davini, vários elementos entram em jogo quando se aborda a voz: "(...) não podemos pensar a voz e a palavra sem pensar o corpo e o sujeito. Mais ainda, pensar a voz, a palavra, o corpo e o sujeito sem considerar a incidência da tecnologia sobre eles, especialmente, a partir do século $X X$, pode comprometer seriamente qualquer tipo de consideração na matéria". (DAVINI, 2008, p. 312).

A inscrição da voz na abordagem da canção, por exemplo, principalmente na canção popular, em que é dada ao intérprete vocal muito maior liberdade de execução, oferece o desafio de se ter de considerar que cada execução transforma a canção em outra: timbre, tessitura, duração, volume incidem sobre a canção, modelam o que está sendo dito, em termos linguísticos e em termos musicais.

Mas como falar de vozes? Esta é uma pergunta já esboçada por Elizabeth Travassos ao indagar acerca da inscrição da voz nos estudos musicológicos. A pesquisadora chama a atenção para o caráter limitado da classificação utilizada pela tradição do bel canto que divide as vozes entre soprano, mezzo soprano, contralto (femininas), tenor, barítono e baixo (masculinas). "Dizer que uma 
jongueira tem voz de contralto não comunica muita coisa importante sobre sua voz, não obstante cheia de idiossincrasias sociais; a prova disso é que, ao tentarmos cantar como ela, beiramos a caricatura" (TRAVASSOS, 2008, p.102). Esta observação diz respeito não apenas à singularidade da voz, mas a seu oposto, àquilo que cada voz traz em si de social. Se isto se torna claro em relação ao exemplo das performances coletivas nas culturas tradicionais, será preciso dizer que elementos como gênero musical e contexto histórico modelam as vozes, tanto no canto quanto na fala.

A voz de um roqueiro, assim como a de um cantor bossa-novista, possui emissões que se adequam ao gênero musical e ao contexto histórico do qual emerge. Se o canto de João Gilberto é um dos produtos da era do microfone também é este suporte material que permite que se tornem audíveis notas com as quais um intérprete não conseguiria cantar a capela. Assim, uma voz feminina classificada como soprano pode tirar partido do microfone para a emissão de notas muito graves para a sua tessitura. Para reforçar a incidência do contexto histórico sobre as vozes individuais, lembro uma observação de Felipe Abreu: “(...) é justo dizer que o papel da mulher transformou-se. Passou a ter voz ativa social, e à medida que passamos a escutar-Ihes as palavras, sua tessitura foi baixando para regiões próximas à da fala (ou vice-versa?). Aplaudimos vozes graves que jamais teriam vez no canto clássico, de Maria Bethania a Cássia Eller, de Bessie Smith a Cesária Évora" (ABREU, 2001, p. 110). A observação permite que se perceba o quanto a voz enquanto materialidade pode significar $\mathrm{e}$ incidir sobre um texto, o que vem a desafiar qualquer possibilidade de que este apresente por si só estabilidade significativa.

Desta forma, o arquivo digital deve ser percebido como um novo objeto de estudo a ser abordado não apenas como transmissor de um conteúdo, mas como materialidade que se diferencia do texto impresso por inúmeras variáveis, desde o tempo e a virtualidade da transmissão, até o fato de poder transportar som e imagem em movimento, o que o torna resistente às tradicionais abordagens de 
textos. Trata-se certamente de uma investigação fortemente ligada aos aspectos sensoriais das novas formas de transmissão e recepção.

Esta reflexão, de fato, não seria possível sem o contato com a obra de Paul Zumthor. Mais do que isto, sem que se atentasse de perto para o fato de que, em dado momento, o medievalista muda seu foco de investigação da oralidade, como meio de transmissão, para a vocalidade em si, trazendo para o centro de suas preocupações a voz enquanto "coisa", que se define por propriedades específicas, como "tom, timbre, alcance, altura, registro" e que se coloca como "presença que se diz a si própria" (ZUMTHOR, 2005, p. 62). Para Zumthor, o privilégio da vocalidade sobre a oralidade diz respeito ao fato de que esta última, tal como a escrita, se define por sua relação com a linguagem da qual a voz enquanto objeto se liberta. Zumthor é, ainda, o responsável pelo amplo trânsito do termo performance nos estudos literários, bem como em outras áreas das ciências humanas e sociais. A performance, como conceito, demanda, por sua vez, que se inscrevam todos os elementos que envolvem uma situação comunicacional.

Neste sentido, é importante frisar que o termo é muitas vezes associado à ideia de fenômeno irrepetível, modelado por circunstâncias espaço-temporais e que o próprio Zumthor o relaciona à possibilidade de mediatização. Desta forma, seria possível falar tanto da performance que dá origem ao arquivo quanto das inúmeras performances que ocorrem a cada execução, modeladas pelas diferentes condições de recepção e fruição, que envolvem desde a qualidade do aparato tecnológico até as condições psicológicas do ouvinte ou ouvinteespectador. De qualquer forma, é importante frisar que, ao tratar das vozes do arquivo digital, é preciso lidar com elementos já tratados por Heloísa Duarte Valente, que desdobra a ideia de voz mediatizada de Zumthor, ao abordar tanto a "voz esquizofônica", possibilitada pelas técnicas de gravação que deram margem à não-coincidência entre os contextos de produção e recepção sonora, quanto a "voz virtual", ou seja, aquela que foi processada e transformada através das intervenções tecnológicas (VALENTE, 1999, p.119-152). A meu ver, essas vozes 
permitem que se retome tanto a ideia de performance, agora aplicada ao próprio fazer tecnológico (a performance do engenheiro acústico, por exemplo), quanto a centralidade que 0 ato da recepção dos arquivos digitais adquire no atual contexto.

Adriana Cavarero chama atenção para alguns aspectos ainda não previstos nas reflexões anteriores: o caráter relacional e a unicidade da voz. O primeiro possibilita que se enfatize a figura do receptor, já que a vocalização pressupõe a escuta de alguém também apto a vocalizar, e o segundo opera como um dispositivo através do qual a pensadora confronta a filosofia ocidental em sua tendência às categorias generalizantes. Esta é a crítica que Cavarero dirige também a Zumthor a quem atribui o mérito de libertar a voz da linguagem e trazêla para "a economia pulsional, ligada aos ritmos do corpo" (CAVARERO, 2011, p. 26), mas que tenderia a tratar a voz ainda como algo genérico. A questão crucial para Cavarero é o confronto da tradição logocêntrica através da denúncia do que ela chama de desvocalização do logos na tradição metafísica, uma operação que "consiste no duplo gesto que separa a palavra e os falantes para assentar a primeira no pensamento ou, se preferir, no significado mental de que a palavra mesma, na sua materialidade sonora, seria expressão, significante acústico, signo audível" (CAVARERO, 2011, p. 24). Desta perspectiva, Cavarero desafia a tese de Derrida que liga a metafísica ao fonocentrismo, a qual contrapõe sua própria teoria de que o elemento-chave da voz é a unicidade.

Ao pleitear a abordagem da voz enquanto unicidade que remete à cena materna e à percepção da palavra em sua origem corpórea, Cavarero confronta a idéia abstrata de sujeito e, ainda, atribui à voz uma dimensão semântica, que residiria nos próprios contornos musicais inerentes ao dizer (CAVARERO, 2011, p. 210211).

Mladen Dolar, assim como Cavarero, responde à tese de Derrida acerca da relação entre logocentrismo e fonocentrismo. Dolar aborda e, ao mesmo tempo, problematiza a voz em seu aspecto sensorial, como elemento acima da 
linguagem e do sentido e que, corpóreo, se manifesta, por exemplo, no canto e no riso e não pode ser separado em traços distintivos. O alvo principal de Mladen Dolar é a fonologia e sua centralização no conceito de fonema e seus traços distintivos: "os fonemas carecem de substância, eles são completamente redutíveis à forma (...) e carecem de qualquer significação própria" (DOLAR, 1996, p.8-9). Para Dolar, a proposta através da qual a sonoridade da língua se reduz à compreensão dos fonemas como feixes de traços distintivos é, antes de tudo, uma forma de liquidação da voz. E isto ocorre justamente porque a voz não interessa à fonologia na medida em que seria na linguagem verbal "o elemento material recalcitrante ao sentido", "o elemento extralinguístico que promove o fenômeno da fala, mas que não pode ser distinguido pela linguística" (DOLAR, 2006, p. 15).

Com isto, o que se percebe é que a passagem da escrita à fala, da escrita à audição da voz é uma passagem em que se transforma completamente tanto para o emissor quanto para o receptor a relação com a produção de significado. E isto se dá porque o corpo, coadjuvante na escrita, passa a uma posição central, na medida em que a voz é dele inseparável.

A possibilidade de receber, em segundos, voz e imagem em arquivos digitais nos coloca, portanto, diante de um processo de corporificação do pensamento que será cada vez mais explorado nos próximos anos pelos usuários da rede de computadores.

Não somente estamos a compartilhar vozes como podemos compartilhar falas no lugar da escrita, com o auxílio de um pequeno gravador. O recurso ainda é pouco explorado, o que evidencia o fato de estarmos a vivenciar um momento de transição em que a palavra escrita apresenta forte prevalência. Entretanto, é possível perceber que, em momentos de forte tensão, como nos episódios das manifestações políticas de 2013 no Brasil, os usuários da rede tendem a recorrer, com mais frequência, ao compartilhamento de arquivos auditivos e audiovisuais que compreendem como mais eficazes como testemunhos e como elementos 
engajadores do que os arquivos que contém somente a palavra escrita.

As consequências dessa guinada em direção à vocalidade que se anuncia com os desdobramentos da cultura digital ainda estão para ser descodificadas, abordadas e contempladas pelas ciências. Por sua vez, parece ser inevitável a reorganização das disciplinas e de suas fronteiras diante deste poderoso instrumento através do qual o humano se reconcilia com sua inumanidade: a voz.

\title{
THE VOICE IN THE DIGITAL ARCHIVE
}

\begin{abstract}
This article examines the impact on the humanities caused by the sharing of audio and audiovisual archives made possible by the contemporary presence of the internet. Therefore, the base assumption is that the phenomenon represents a shift towards vocality that, with it, brings about significant changes in the relationship between thought and language, as compared to print culture. The main effect that is caused by the voice's material presence is a process of embodiment, in which the sensory becomes inseparable from the communicative act, as opposed to the process that happens with printed paper and the consequent process of printed text's empowerment.
\end{abstract}

KEYWORDS: Voice. Humanities. Arquive. Press. Body.

\section{REFERÊNCIAS}

ALMEIDA, T.V. A voz como provocação aos estudos literários. Outra Travessia. Florianópolis, n. 11, PPGL, 2011, p.115-129.

ABREU, F. A questão da técnica vocal ou a busca da harmonia entre música e palavra. In: MATTOS, C. et alli. Ao encontro da palavra cantada. Rio de Janeiro: 7 letras, 2001, p. 104-112.

AGAMBEN, G. O que é o contemporâneo. In: 0 que é o contemporâneo e outros ensaios. Chapecó: Argos, 2009.

BOURDIEU, P. A economia das trocas simbólicas. São Paulo: Perspectiva, 1992.

CAVARERO, A. Vozes plurais: filosofia da expressão vocal. Tradução de Flavio Terrigno Barbeitas. Belo Horizonte: UFMG, 2011.

DAVINI, S. Voz e palavra: música e ato. In: MATTOS, C. Palavra cantada: ensaios sobre poesia, música e voz. Rio de Janeiro: 7 Letras, 2008, p. 307315. 
DOLAR, M. The object voice. In: ZIZEK, Slavoj e SALECL, Renata. Gaze and voice as love objects. Durham, London: Duke University Press, 1996, p. 7-31.

A voice and nothing more. Masachusetts: MIT Press, 2006.

DERRIDA, J. Mal de arquivo: Uma impressão freudiana. Tradução de Claudia de Moraes Rego. Rio de Janeiro: Relume Dumará, 2001

FOUCAULT, M. Arqueologia do saber. Tradução de Luiz Felipe Baeta Neves. Rio de Janeiro: Forense Universitária,1995.

As palavras e as coisas. Tradução de Salma Tannus Muchail. São Paulo: Martins Fontes, 1995.

GUMBRECHT, H.U. Corpo e forma. Rio de Janeiro: EDUERJ, 1998.

1998.

. Modernização dos sentidos. São Paulo: 34 letras,

HEIM, M. Electric language: a philosophical study of word processing. New Haven \& London: Yale University Press, 1987.

University Press, 199,

The methaphysics of virtual reality. New York: Oxford

LEVY, P. Becoming virtual: reality in the digital age. Translated by Robert Bononno. New York and London: Plenum Trade, 1998.

MORIN, E. A cabeça bem feita. Tradução de Eloá Jacobina. 8a. edição, Rio de Janeiro: Bertrand Brasil, 2003.

TRAVASSOS, E. Um objeto fugidio: voz e 'musicologias'. In: MATTOS, C. et alli. Palavra cantada: ensaios sobre poesia, musica e voz. Rio de Janeiro: 7 Letras, 2008, p. 99-123.

ZUMTHOR, P. Escritura e nomadismo. São Paulo: Ateliê Editorial, 1999.

A letra e a voz. São Paulo: Companhia das Letras, 2001.

Performance, recepção, leitura. São Paulo: Cosac Naify, 2007.

Texto recebido em 25/10/2013.

Texto aprovado em 29/11/2013. 